\title{
Pemberdayaan masyarakat dalam meningkatkan nilai tambah hasil perikanan di Kelurahan Pangkalan Lesung Kabupaten Pelalawan
}

\author{
Trisla Warningsih*, Kusai, Lamun Bathara, Zulkarnain, \& Isma Mulyani \\ Universitas Riau \\ * trisla.warningsih4455@gmail.com
}

\begin{abstract}
Abstrak. Kelurahan Pangkalan Lesung terletak di Kecamatan Pangkalan Lesung Kabupaten Pelalawan Provinsi Riau. Kelurahan Pangkalan Lesung memiliki potensi wisata alam berupa tempat pemandian air panas, keberadaan kawasan wisata alam dapat meningkatkan perekonomian sektor informal melalui penyediaan makanan untuk wisatawan yang berkunjung. Salah satu alternatif makanan yang bisa dilakukan adalah olahan dari produk perikanan. Olahan produk perikanan selain memiliki kandungan gizi yang baik bagi kesehatan juga memiliki nilai ekonomi yang cukup tinggi, dimanfaatkan sebagai produk olahan pangan dan menambah penghasilan keluarga. Tujuan kegiatan untuk menberdayakan masyarakat di Kelurahan Pangkalan Lesung, Pelalawan agar dapat mengolah hasil perikanan menjadi olahan yang variatif dan siap saji. Namun tetap sehat untuk dikonsumsi keluarga karena dikreasikan dengan berbagai jenis sayur dan ikan. Manfaat kegiatan yaitu masyarakat Kelurahan Pangkalan Lesung mendapatkan kemampuan dan keterampilan dalam pembuatan nugget dan bakso ikan yang bernilai gizi tinggi, meningkatkan perekonomian masyarakat serta dapat dikembangkan untuk usaha lanjutan. Metode yang dilakukan adalah demonstrasi dan praktek mengenai cara mengolah produk perikanan. Masyarakat sasaran kegiatan ini adalah ibu PKK yang beranggotakan 25 orang. Hasil evaluasi peserta menerima dan mempraktekkan materi pengolahan produk hasil perikanan untuk dijadikan kewirausahaan pada acara 17 Agustus 2019 di Kelurahan Pangkalan Lesung.
\end{abstract}

Kata kunci: Pangkalan Lesung; wisata pemandian air panas; nilai tambah; produk perikanan

\begin{abstract}
Pangkalan Lesung Urban Village is located in Pangkalan Lesung District, Pelalawan Regency, Riau Province. Pangkalan Lesung Urban Village has the potential for natural tourism in the form of hot spring baths, the existence of a nature tourism area can improve the economy of the informal sector through the provision of food for tourists who visit. One alternative food that can be done is processed from fishery products. In addition to having processed fishery products that have good nutritional content for health, they also have a high economic value, are used as processed food products and increase family income. The aim of the activity is to empower the community in Pangkalan Lesung Village, Pelalawan to be able to process fishery products into varied and ready-to-serve products. But still healthy for family consumption because it is created with various types of vegetables and fish. The benefit of the activity is that the community of Pangkalan Lesung Village gets the ability and skills in making fish nuggets and meatballs which have high nutritional value, improve the community's economy and can be developed for further business. The method used is a demonstration and practice on how to process fishery products. The target community for this activity is PKK, with 25 members. The results of the evaluation of participants receiving and practicing the material processing of fishery products to be used as an entrepreneurship on the 17 August 2019 in Pangkalan Lesung Village.
\end{abstract}

Keywords: Pangkalan Lesung; hot spring tourism; value added; fishery products

To cite this article: Warningsih, T., Kusai, L. Bathara, Zulkarnain, \& I. Mulyani. 2019. Pemberdayaan masyarakat dalam meningkatkan nilai tambah hasil perikanan di Kelurahan Pangkalan Lesung Kabupaten Pelalawan. Unri Conference Series: Community Engagement 1: 555-563 https://doi.org/10.31258/unricsce.1.555-563

(C) 2019 Authors

Peer-review under responsibility of the organizing committee of Seminar Nasional Pemberdayaan Masyarakat 2019 


\section{PENDAHULUAN}

Pariwisata merupakan kesatuan dari beberapa elemen seperti wisatawan, daerah tujuan wisata, perjalanan, industri dan lain sebagainya yang merupakan kegiatan pariwisata. Indonesia memiliki beraneka ragam jenis pariwisata seperti wisata alam, sosial maupun wisata budaya yang menjadi sumber devisa negara (Devy \& Soemanto, 2017). Wisata alam merupakan bentuk kegiatan wisata yang memanfaatkan potensi sumberdaya alam dan tata lingkungan yang meliputi objek dan kegiatan yang berkaitan dengan rekreasi dan pariwisata yang memanfaatkan potensi sumberdaya alam dan ekosistemnya, baik dalam bentuk asli (alami) maupun perpanduan dengan buatan manusia (Suwantoro, 2002).

Kelurahan pangkalan lesung memiliki potensi wisata alam berupa tempat pemandian air panas, yang menjadi salah satu destinasi wisata alternatif bagi masyarakat. Aktifitas yang dilakukan adalah berendam untuk merelaksasi tubuh dari kepenatan menjalani rutinitas. Pemandian air panas di pangkalan lesung ini mampu menyembuhkan berbagai penyakit kulit seperti gatal-gatal, kurap dan juga bisa menyembuhkan rematik dan pegal-pegal. Keberadaan Kegiatan wisata pemandian air panas ini akan mempengaruhi keadaan masyarakat Pangkalan Lesung sehingga meningkatkan perekonomian sektor informal melalui penyediaan makanan untuk wisatawan yang berkunjung.

Selain itu, Pangkalan Lesung juga memiliki potensi sektor perikanan terutama air tawar sehingga menarik perhatian untuk mengolah hasil perikanan menjadi lebih bernilai. Salah satu alternatif makanan yang bisa dilakukan adalah hasil olahan dari daging ikan Patin. Herawati (2002) mengatakan pengolahan ikan yang dilakukan di Indonesia masih tergolong tradisional pada skala industri rumah tangga. Daging ikan Patin dapat diolah menjadi berbagai macam produk seperti snack amplang, mi sagu instan, biskuit, snack, baso, nugget siap saji (Dewita et al., 2010; Dewita et al., 2011; Desmelati et al., 2013; Dewita \& Sahrul, 2014; Syahrul et al., 2018) ketersediaan makanan siap saji yang bersifat ready to cook and ready to eat sangat dibutuhkan oleh masyarakat (Asrawaty \& If'all, 2018).

Pelatihan pengolahan ikan patin menjadi produk olahan pangan dapat menambah pengetahuan dalam memperoleh mata pencaharian alternatif. Ketersediaan makanan jajanan di tempat wisata pemandian air panas akan lebih meningkatkan daya kunjung serta memberikan kenyamanan bagi wisatawan yang datang karena dengan mudah memperoleh makanan sehingga akan menambah penghasilan masyarakat yang ada di Kelurahan Pangkalan Lesung.

\section{METODE PENERAPAN}

Metode yang digunakan dalam kegiatan pengabdian ini antara lain: ceramah, diskusi, praktek langsung, dengan materi yang disampaikan berupa: 1) metode meningkatkan nilai tambah hasil perikanan dengan bahan baku ikan patin, 2) teknik pembuatan nugget dan bakso dari olahan ikan patin serta tambahan beberapa sayur seperti wortel dan daun seledri, 3) metode packaging (pengemasan) dan labelling (pemberian label), 4) penyimpanan produk dan manajemen pengendalian mutu untuk menjamin keamanan produk, 5) strategi pemasaran nugget dan bakso ikan patin, 6) manajemen usaha.

\section{Persiapan}

Persiapan awal yang dilakukan antara lain: 1) sosialisasi program. Setelah ditemukan adanya potensi hasil perikanan yang melimpah dan dapat dikembangkan, maka mendukung pelaksanaan pemberdayaan masyarakat dalam meningkatkan nilai tambah hasil perikanan di Kelurahan Pangkalan Lesung, Pelalawan, 2) penyiapan bahan (daging ikan patin fillet, tepung terigu, tepung kanji, tepung sagu, tepung meizena, tepung panir, es batu, royco, merica, bawang merah, bawang putih, bawang goreng, roti tawar, telur, garam, bumbu kenyal, wortel, seledri dll) dan alat pengolahan (pisau cutter, pelumat daging, termos kecil, mangkok, loyang, kertas roti, plastik, timbangan, panci dandang, kuali, piring melamin, baskom, saring, sendok goreng, kuas kue, container box, sendok nasi, talenan, tisu, serbet, dll). Selain itu dipersiapkan resep pembuatan nugget dan bakso ikan patin serta penyediaan contoh nugget dan bakso ikan patin yang sudah jadi 3) mempromosikan hasil produk olahan perikanan di Kelurahan Pangkalan Lesung 4) pendampingan pengelolaan produk pemasaran dan pengembangan jika diperlukan, 5) monitoring. Terhadap masyarakat sasaran apakah telah melaksanakan teknik dalam meningkatkan nilai tambah hasil perikanan.

\section{Pelaksanaan}

Palaksanaan kegiatan ini dimulai dengan 1) pembukaan oleh ketua tim penggerak PKK,2) penyampaian materi pengabdian oleh ketua tim pengabdian FPK Universitas Riau, meliputi: 1) potensi perikanan, 2) kandungan 
gizi pada ikan, 3) olahan ikan berbentuk nugget, bakso, dll serta cara pengolahannya, 4) bahan, cara pengemasan dan pemberian label produk, 5) strategi pemasaran.

Selanjutnya dilakukan praktek secara langsung untuk pembuatan nugget dan bakso dari olahan ikan patin bersama ibu PKK yang dibimbing oleh tim pengabdian FPK Universitas Riau.

\section{Prosedur Pengambilan Daging Ikan Patin}

Adapun langkah-langkah dalam pengambilan daging ikan patin adalah sebagai berikut: 1) cuci bersih ikan dan buang sisiknya, 2) dari bagian ekor fillet dan tarik keatas ke bagian kepala dengan menggunakan pisau cutter, kemudian fillet tipis dan rapi sehingga seluruh bagian daging terangkat. Lakukan di kedua sisi pada ikan 3) buang duri yang masih tersisa pada daging ikan.

\section{Pembuatan Nugget Ikan Patin}

Nugget merupakan produk olahan dari bahan pangan segar seperti daging, ayam, ikan dll. Nugget kini telah berkembang dengan semua bahan baku yang akan diolah menjadi sebuah aneka makanan.

Bahan-bahan Pembuatan Nugget ikan terdiri dari Ikan patin fillet 700 gr, tepung terigu 100 gr, tepung sagu 100 gr tepung kanji 100 gr, tepung meizena 100 gr, tepung panir secukupnya, air es $150-300 \mathrm{cc}$ tergantung jenis ikan, royco 1,5 bungkus, merica 1 sendok teh, bawang merah 80 gr, bawang putih 20 gr, roti tawar 5 buah, putih telur secukupnya, kuning telur 1 butir, seledri, wortel dan garam secukupnya.

\section{Pembuatan Bakso Ikan Patin}

Adapun bahan-bahan pembuatan bakso ikan antara lain: ikan patin $2 \mathrm{~kg}$ (fillet $2 \mathrm{~kg}$ ), tepung sagu $1 / 4(14$ sendok makan), tepung terigu ( 3 sendok makan), bawang putih 6 siung, bawang goreng secukupnya, merica 1 sachet, garam 1 sendok teh, bumbu kenyal bakso 1 bungkus, telur 1 butir, seledri secukupnya dan es batu $50 \mathrm{ml}$.

\section{Packaging (Pengemasan) dan Labelling (Pembuatan Label)}

Produk olahan nugget dan bakso ikan patin dimasukkan kedalam kemasan plastik yang menarik dan sudah diberi lebel. Kemudian kemasan plastik ditutup rapat. Setelah itu aneka makanan olahan nugget dan bakso ikan patin yang telah dikemas siap disimpan dipromosikan, dan dipasarkan, baik di Pangkalan Lesung, dikawasan wisata sehingga bisa menjadi mata pencaharian alternatif masyarakat.

\section{Penyajian}

Nugget bisa langsung dimakan setelah di kukus, dibalur tepung panir dan digoreng. Sedangkan bakso selain bisa dimakan langsung juga bisa digoreng diberi sambal atau dengan kuah.

\section{Jadwal Kegiatan}

Jadwal pelaksanaan kegiatan pengabdian kepada masyarakat dilakukan pada bulan Juli sampai Agustus 2019.

\section{HASIL DAN KETERCAPAIAN SASARAN}

\section{Masyarakat Sasaran}

Masyarakat yang dijadikan sasaran kegiatan ini adalah ibu PKK yang beranggotakan 25 orang. Diketahui bahwa tidak semua anggota PKK mampu membuat hasil olahan perikanan, maka dilakukan praktek secara langsung oleh peserta dan dibimbing oleh Tim Pengabdian FPK Universitas Riau. Bahan-bahan dan alat untuk pengolahan nugget dan bakso ikan patin disediakan oleh Tim FPK Universitas Riau, kemudian diserahkan kepada ibu PKK. Penyerahan alat (Gambar 1) oleh tim Pengabdian Masyarakat FPK Universitas Riau kepada ibu PKK di Kelurahan Pangkalan Lesung guna memberikan dorongan kepada masyarakat untuk lebih bersemangat lagi dalam membuat olahan produk perikanan.

Tim Pengabdian FPK Universitas Riau mengharapkan dari pelaksanaan kegiatan ini mampu membuat ibu PKK menjadikan olahan berbahan dasar perikanan sebagai olahan sendiri maupun dikembangkan untuk usaha selanjutnya, serta diharapkan dapat menjadi mata pencaharian alternatif oleh masyarakat, terutama untuk kewirausahaan yang dijual pada lokasi wisata pemandian air panas Kelurahan Pangkalan Lesung. 


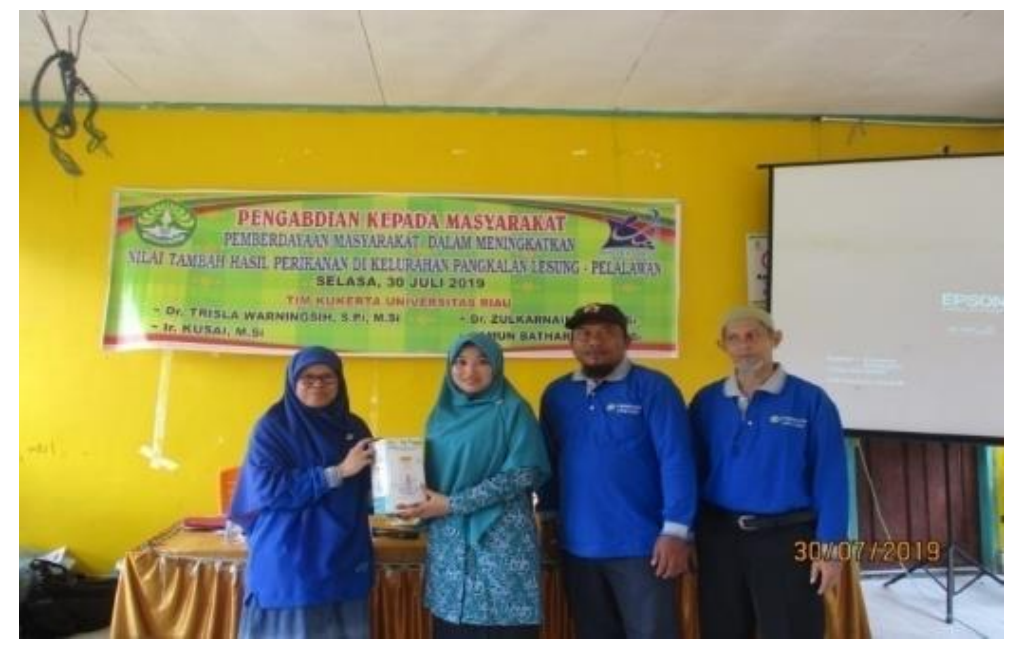

Gambar1. Penyerahan Alat oleh ketua Tim Pengabdian FPK Universitas Riau kepada tim penggerak Pemberdayaan Kesejahteraan Keluarga (PKK)

\section{Penyampaian Materi}

Penyampaian materi dilakukan di balai kantor Kelurahan Pangkalan Lesung (Gambar 2) penyajian materi diawali dengan kata sambutan oleh ketua PKK, kemudian penyampaian materi oleh ketua Tim Pengabdian FPK Universitas Riau Dr. Trisla Warningsih, S.Pi, M.Si. Kegiatan ini melibatkan secara aktif mahasiswa kukerta Universitas Riau 2019. Sebelum penyampaian materi, masyarakat selaku peserta dibagikan deskripsi bahan ajar untuk memudahkan dalam memahami materi yang akan disampaikan. Materi berupa:

- Penjelasan mengenai potensi perikanan di Kelurahan Pangkalan Lesung, Pelalawan

- Kandungan gizi pada ikan

- Prosedur pembuatan olahan nugget dan bakso ikan patin

- Bahan, cara pengemasan dan pemberian lebel pada produk

- Strategi pemasaran produk olahan
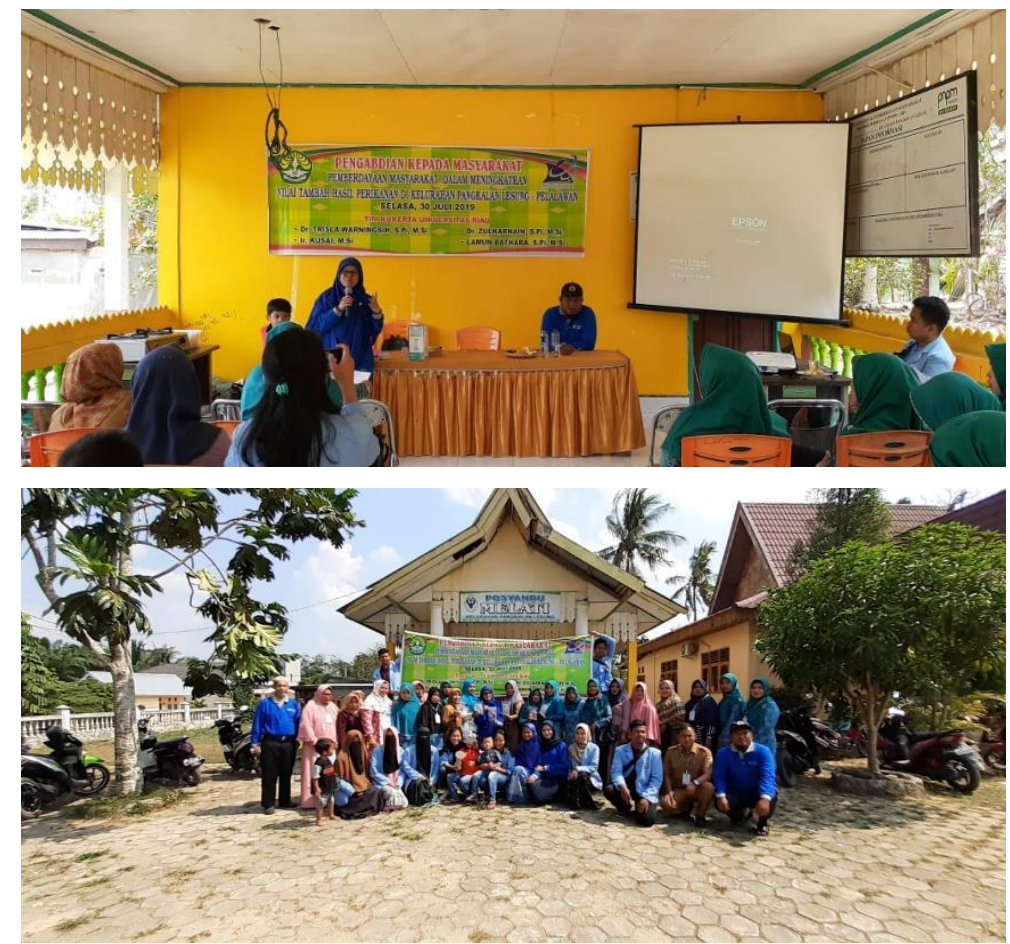

Gambar 2. Penyampaian materi pengabdian oleh ketua tim pengabdian FPK Universitas Riau

Selama penyampaian materi peserta juga dipersilahkan untuk mengajukan pertanyaan terhadap materi yang kurang dipahami. Diskusi berjalan dengan baik, bahkan sebagian besar peserta antusias agar segera dilakukan 
praktek secara langsung. Kerjasama dalam kegiatan ini dapat ditingkatkan dalam memberi informasi mengenai produk olahan perikanan. Pangkalan Lesung juga memiliki potensi sektor perikanan air tawar sehingga menambah ketertarikan masyarakat dalam mengolah produk hasil perikanan tersebut menjadi lebih bernilai.

\section{Praktek Pembuatan Nugget dan Bakso Ikan Patin}

\section{Pembuatan Nugget Ikan Patin}

Praktek pembuatan nugget ikan patin, pertama fillet ikan, air es dan roti tawar di blender, lalu dicampur dengan bumbu yang sudah halus (bawang merah, bawang putih, merica, garam, royco) dan kuning telur. Setelah halus (tercampur rata dan lembut), kemudian ditambah tepung terigu, tepung sagu, dan tepung meizena aduk hingga rata. Siapkan loyang yang sudah diberi kertas roti yang sudah diolesi dengan minyak goreng, kemudian adonan dimasukkan kedalam loyan kemudian diratakan. Kukus adonan selama +- 20 menit. Setelah adonan matang, diiris sesuai selera kemudian adonan dimasukkan kocokan putih telur dan dibalut dengan tepung panir, lalu masukkan ke dalam putih telur kembali dengan tepung panir, nugget ikan patin di goreng. Disajikan dengan sambal selagi panas.

\section{Pembuatan Bakso Ikan Patin}

Praktek pembuatan bakso bersama pesera dengan memasukkan fillet ikan patin, bawang putih dan bawang merah kemudian digiling atau di blender menggunakan air es. Setelah halus masukkan telur, bumbu bakso kemudian giling kembali. Campurkan tepung sagu dan tepung terigu sambil diaduk hingga tercampur rata. Kemudian masukan adonan ketempat kering campurkan keduanya sambil diaduk hingga rata. Kemudian bulatkan lalu masukkan kedalam air mendidih.
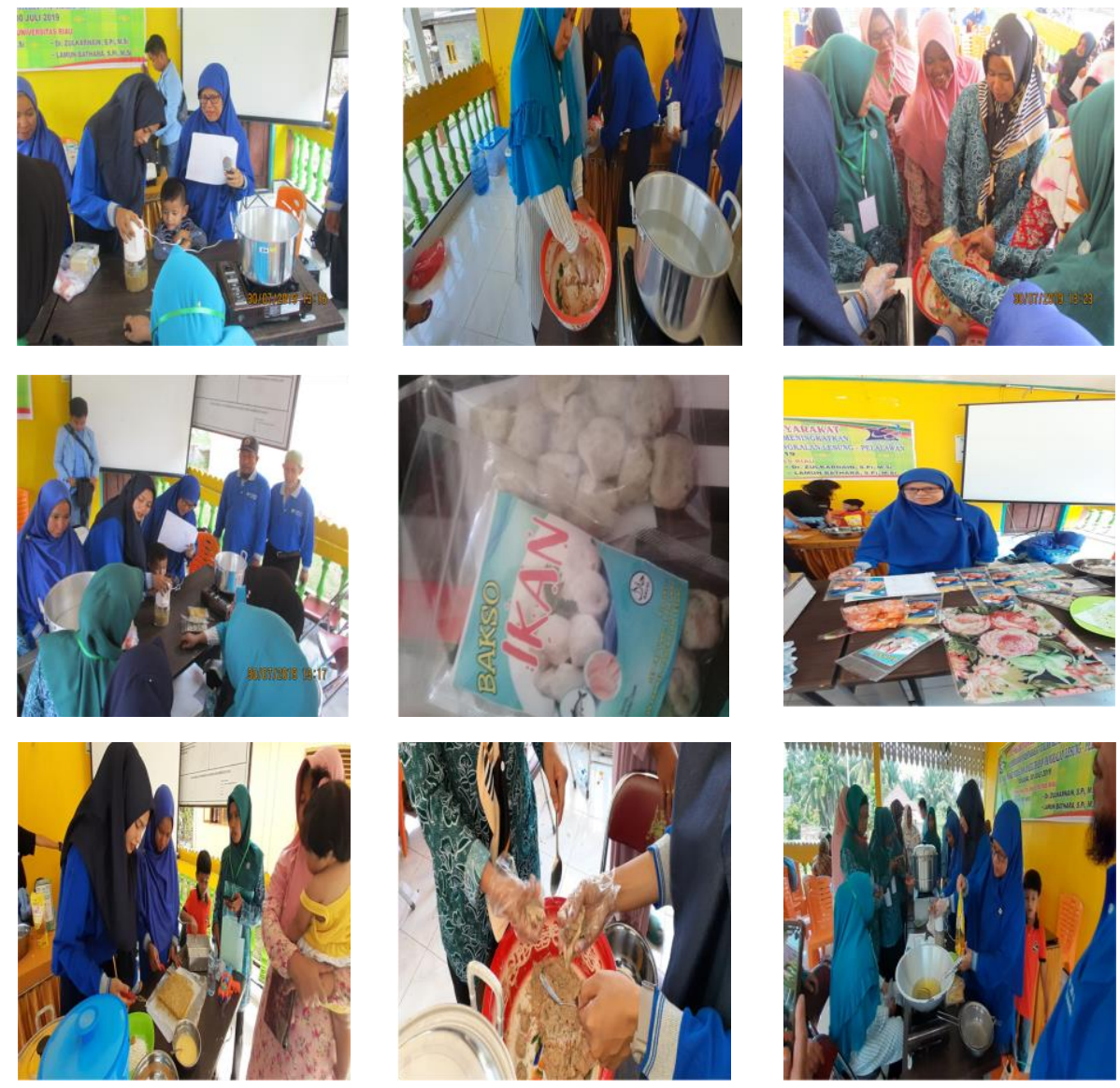

Gambar 3. praktek pembuatan nugget dan bakso ikan patin

Berdasarkan Gambar 3 dapat dilihat bahwa kegiatan ini memberikan dampak positif bagi pemberdayaan masyarakat dalam meningkatkan pengetahuan dan keterampilan yaitu berupa kewirausaahan berbahan dasar perikanan dalam meningkatkan penghasilan keluarga. tim pengabdian FPK Universitas Riau telah dibekali 
ilmu dan keterampilan dalam membuat olahan produk perikanan dan manajemen usaha serta strategi pemasaran khususnya di tempat wisata.

\section{Monitoring dan Evaluasi}

Kegiatan pengabdian dilakukan untuk memberikan pengetahuan dan menambah kemampuan masyarakat Kelurahan Pangkalan Lesung supaya dapat memanfaatkan potensi sektor perikanan air tawar berupa olahan pangan siap saji yang lebih bernilai ekonomi dan dapat membantu masyarakat dalam memenuhi kebutuhannya. Olahan berbahan dasar ikan ini menjadi produk yang dapat diolah sendiri maupn dikembangkan untuk usaha lanjutan ke depannya.

Setelah masyarakat menerima pelatihan kemudian mempraktekkan teknik pengolahan produk hasil perikanan, setelah dua minggu kegiatan dilakukan monitoring dan evaluasi. Hasil monitoring menunjukkan bahwa praktek membuat olahan produk perikanan oleh masyarakat sebagai usaha serta perlombaan HUT RI pada 17 Agustus 2019 di Pangkalan Lesung (Gambar 4)
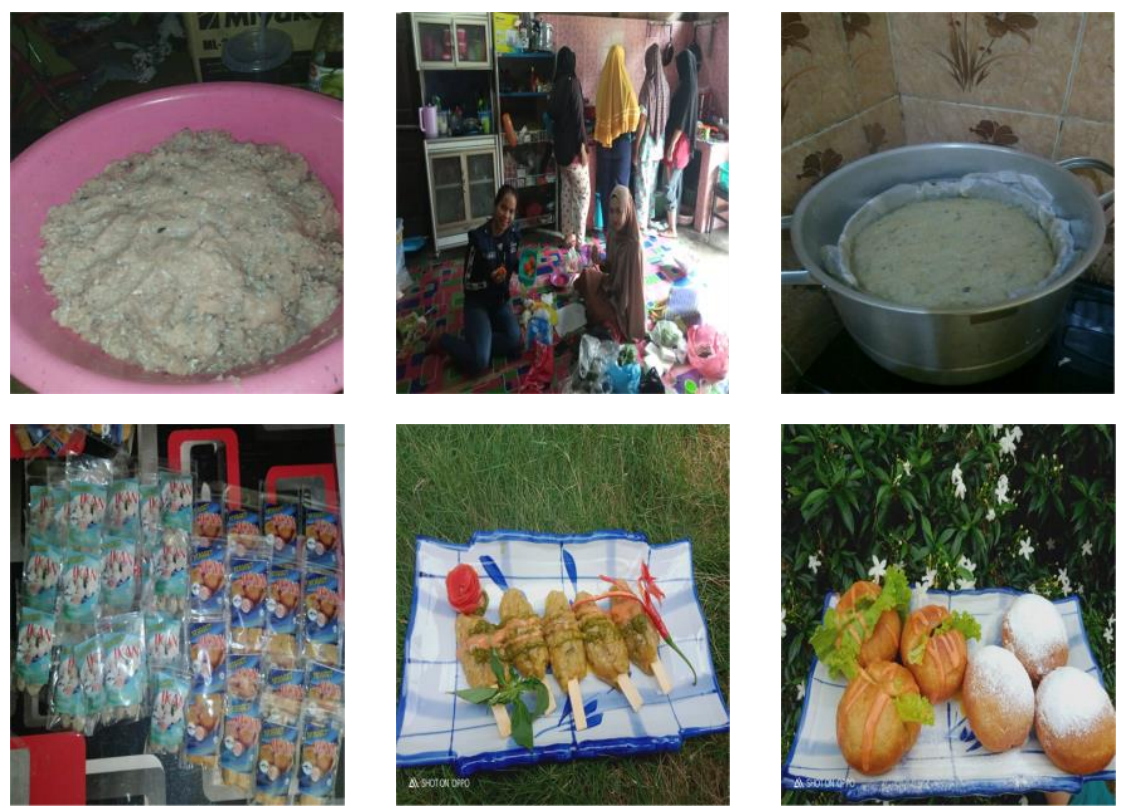

Gambar 4. Produk Olahan Hasil Perikanan

Ikan air tawar di Pangkalan Lesung berpotensi dikembangkan menjadi produk olahan. Selain produk perikanan memiliki nilai banyak kandungan gizi yang yang dibutuhkan dengan harga yang terjangkau sehingga menjadikan salah satu priduk olahan pangan yang paling dicari serta dapat dikombinasikan dengan sayur. Namun kelemahannya diketahui bahwa produk perikanan cepat mengalami oksidasi menyebabkan bau tengik dan keterbatasan pemasaran.

\section{Tingkat Ketercapaian Sasaran Program}

Tahap selanjutnya merupakan monitoring pemasaran produk olahan perikanan, serta evaluasi dari kegiatan berdasarkan keterampilan masyarakat dalam membuat olahan produk. Produk olahan dapat diberikan label bakso ikan, nugget ikan, dll dalam memudahkan proses pemasaran. Faktor pendapatan dan harga merupakan faktor utama dalam permintaan pasar. Keuntungan dapat diperoleh masyarakat berdasarkan analisis perhitungan biaya olahan produk perikanan pangan berupa nugget dan bakso ikan. Seperti dilihat pada (Tabel $1)$.

Tabel 1. Biaya Tetap Nugget dan Bakso Ikan Patin

\begin{tabular}{lcccr}
\hline & Kumlah & Harga Satuan & Umur Teknis \\
Komponen & Barang & (Rp) & $\begin{array}{c}\text { Biaya peyusutan } \\
\text { (Rp) }\end{array}$ \\
\hline Loyang & 2 & 23.000 & 36 & 1.278 \\
Tabung Gas & 1 & 175.000 & 36 & 4.861 \\
Sendok Goreng & 1 & 22.000 & 36 & 611 \\
Kompor Gas & 1 & 340.000 & 36 & 9.444 \\
\hline
\end{tabular}




\begin{tabular}{lcccr}
\hline \multicolumn{1}{c}{ Komponen } & Jumlah & Harga Satuan & Umur Teknis \\
Barang & (Rp) & $\begin{array}{c}\text { Biaya peyusutan } \\
(\mathrm{Rp})\end{array}$ \\
\hline Regulator Gas & 1 & 80.000 & 36 & 2.222 \\
Pelumat Daging & 1 & 240.000 & 60 & 4.000 \\
Termos Kecil & 1 & 95.000 & 36 & 2.639 \\
Timbangan 2 Kg & 1 & 58.000 & 36 & 1.611 \\
Panci Dandang & 1 & 150.000 & 60 & 2.500 \\
Kuali & 1 & 62.000 & 24 & 2.583 \\
Baskom & 2 & 50.000 & 48 & 2.083 \\
Container Box C.75 & 1 & 125.000 & 48 & 2.604 \\
Mangkok & 2 & 12.000 & 24 & 1.000 \\
\hline Jumlah & & & & 37.438 \\
\hline
\end{tabular}

Tabel 2. Biaya Variabel Nugget dan Bakso Ikan Patin

\begin{tabular}{|c|c|c|c|c|}
\hline No. & Komponen & Jumlah Barang & Biaya (Rp) & $\begin{array}{c}\text { Biaya } \\
\text { (Rp/bulan) }\end{array}$ \\
\hline \multicolumn{5}{|c|}{ Biaya variabel nugget ikan } \\
\hline 1 & Ikan Patin & $1 \mathrm{~kg}$ & 20.000 & 400.000 \\
\hline 2 & Tepung Terigu & $100 \mathrm{gr}$ & 900 & 18.000 \\
\hline 3 & Tepung Sagu & $100 \mathrm{gr}$ & 900 & 18.000 \\
\hline 4 & Tepung Meizena & $100 \mathrm{gr}$ & 1.200 & 24.000 \\
\hline 5 & Tepung Kanji & secukupnya & 2.500 & 50.000 \\
\hline 6 & Tepung Panir & secukupnya & 9.000 & 180.000 \\
\hline 7 & Royco & 1,5 bungkus & 2.000 & 40.000 \\
\hline 8 & Merica & 1 sendok teh & 1.000 & 20.000 \\
\hline 9 & Bawang Merah & $80 \mathrm{gr}$ & 2.560 & 51.200 \\
\hline 10 & Bawang Putih & $20 \mathrm{gr}$ & 4.000 & 80.000 \\
\hline 11 & Roti Tawar & $1 / 2$ bungkus & 7.000 & 140.000 \\
\hline 12 & Telur & 6 butir & 9.000 & 180.000 \\
\hline 13 & Seledri & secukupnya & 3.000 & 60.000 \\
\hline 14 & Wortel & secukupnya & 6.000 & 120.000 \\
\hline 15 & Garam & secukupnya & 2.000 & 40.000 \\
\hline 16 & Minyak Goreng & 1 liter & 13.000 & 260.000 \\
\hline 17 & Kertas Roti & 1 lembar & 1.250 & 25.000 \\
\hline 18 & Label Kemasan & 20 buah & 30.000 & 600.000 \\
\hline 19 & Gas $3 \mathrm{~kg}$ & 1 buah & 20.000 & 400.000 \\
\hline \multicolumn{2}{|c|}{ Jumlah } & & 135.310 & 2.706 .200 \\
\hline \multicolumn{5}{|c|}{ Biaya variabel bakso ikan } \\
\hline 1 & Ikan Patin & $2 \mathrm{~kg}$ & 40.000 & 800.000 \\
\hline 2 & Tepung Sagu & $1 / 4 \mathrm{~kg}$ & 11.250 & 225.000 \\
\hline 3 & Tepung Terigu & $1 / 4 \mathrm{~kg}$ & 2.250 & 45.000 \\
\hline 4 & Bawang Putih & 6 siung & 2.000 & 40.000 \\
\hline 5 & Bawang Goreng & secukupnya & 10.000 & 200.000 \\
\hline 6 & Merica & 1 sachet & 1.500 & 30.000 \\
\hline
\end{tabular}




\begin{tabular}{clcrr}
\hline No. & & & & \\
Komponen & Jumlah Barang & Biaya (Rp) & $\begin{array}{c}\text { Biaya } \\
\text { (Rp/bulan) }\end{array}$ \\
\hline 7 & Garam & 1 sendok teh & 1.000 & 20.000 \\
8 & Bumbu Kenyal Bakso & 1 sachet & 5.000 & 100000 \\
9 & Telur & 1 butir & 1.500 & 30000 \\
10 & Seledri & secukupnya & 3.000 & 60000 \\
11 & Label Kemasan & 20 buah & 20.000 & 400000 \\
\hline Jumlah & & & 97.500 & 1.950 .000 \\
\hline
\end{tabular}

Produksi nugget ikan dan bakso dilakukan sebanyak 2 kali dalam satu bulan. Biaya total yang dikeluarkan selama satu bulan adalah sebesar Rp.2.743.638 untuk nugget ikan dan Rp.1.987.438. Sedangkan total produksi yang dihasilkan adalah 400 bungkus untuk nugget dan 400 bungkus untuk bakso dengan harga sebesar Rp. 10.000. maka total penerimaan masing-masing yang diperoleh sebesar Rp.4.000.000. Laba bersih yang dihasilkan adalah Rp.2.012.563 untuk nugget ikan dan Rp.1.256.363. Produksi olahan produk perikanan yang dibuat oleh masyarakat terlaksana dengan baik serta dapat menjadi nilai tambah ekonomi masyarakat dalam memenuhi kebutuhan.

\section{KESIMPULAN}

Kesimpulan dari kegiatan pengabdian ini, secara umum ketertarikan peserta terhadap pembuatan nugget dan bakso dari ikan patin sangatlah besar. Setelah disampaikan beberapa materi mengenai potensi perikanan serta kandungan gizi dari produk perikanan, menambah semangat para peserta untuk melakukannya sendiri. Dilihat dari keikutsertaan pesertaan terhadap pelatihan ini, maka dapat dikatakan bahwa keinginan peserta untuk membuka usaha sangat tinggi. Keterampilan dan pengetahuan dari peserta juga bertambah setelah adanya praktek olahan nugget dan bakso dari ikan patin.

\section{UCAPAN TERIMA KASIH}

Ucapan terima kasih disampaikan kepada Lembaga Penelitian dan Pengabdian Masyarakat Universitas Riau selaku pemberi dana, Lurah Pangkalan Lesung Ibu Asmaini SE, Ketua PKK Pangkalan Lesung Ibu Yunita Indriani, mahasiswa kukerta dan Jurusan SEP FPK UNRI yang telah berkontribusi besar dalam pelaksanaan kegiatan ini.

\section{DAFTAR PUSTAKA}

Asrawaty, A., \& I. If'all. 2018. Perbandingan Berbagai Bahan Pengikat Dan Jenis Ikan Terhadap Mutu Fish Nugget. Jurnal Galung Tropika 7(1).

Desmelati, Dewita, \& M. Sukmiwati. 2013. Optimalisasi Formula Rasa mie sagu instan yang Difortifikasi Konsentrat Protein Ikan Patin (Pangasius hypothalamus) Sebagai Makanan Potensial Bergizi Tinggi. Jurnal Penelitian Pertanian BERNAS 9(1):7-16.

Devy, H. A., \& R. B. Soemanto. 2017. Pengembangan Obyek Dan Daya Tarik Wisata Alam Sebagai Daerah Tujuan Wisata di Kabupaten Karanganyar (Studi Kasus Obyek Wisata Air Terjun Jumog di Kawasan Wisata Desa Berjo, Kecamatan Ngargoyoso, Kabupaten Karanganyar). Jurnal Sosiologi DILEMA 32(1).

Dewita, \& Sahrul. 2014. Fortifikasi Konsentrat Protein Ikan Patin Siam Pada Produk Snack Amplang Dan Mi Sagu Instan Sebagai Produk Unggulan Daerah Riau. Jurnal Pengolahan Hasil Perikanan Indonesia 17(2): 156-164.

Dewita, Suparmi, \& Syahrul. 2010. Diversifikasi dan Fortifikasi produk olahan berbasis Ikan Patin. Jurnal Teknologi Hasil Perikanan Fakultas Perikanan dan Ilmu Kelautan Universitas Riau I (1): 112-120.

Dewita, Syahrul, \& Isnaini. 2011. Pemanfaatan Konsentrat Protein Ikan Patin (Pangasius Hypothalamus) Untuk Pembuatan Biskuit dan Snack. Jurnal Pengolahan Hasil Perikanan Indonesia 1:30-34.

Herawati, E. S. 2002. Pengolahan Ikan Secara Tradisional: Prospek dan Peluang Pengembangan. Jurnal Penelitian dan Pengembangan Pertanian 21(3). 
Suwantoro, G. 2002. Dasar-dasar Pariwisata, Upaya Pengembangan Pariwisata Alternatif. Yogyakarta: Penerbit Andhi.

Syahrul, Dewita, \& Restu. 2018. Implementasi pewarna alami untuk diversifikasi mie sagu ikan pada pelaku usaha mikro mie sagu di Kabupaten Kepulauan Meranti, Riau. Riau Journal of Empowerment 1(1): 31-36. https://doi.org/10.31258/raje.1.1.4 